MedieKultur | Journal of media and communication research | ISSN 1901-9726

Book Review

\title{
Ansa Lønstrup, Anders Bonde, Nina Gram og Charlotte Rørdam Larsen: Blik for lyd. Forlaget Klim. 2014
}

\author{
Andreas Halskov
}

MedieKultur 2017, 62, 140-142

\section{Published by SMID | Society of Media researchers In Denmark | www.smid.dk The online version of this text can be found open access at www.mediekultur.dk}

I akademiske bøger om lyd er der efterhånden tradition for at fremsætte den samme velkendte hypotese: Det visuelle overprioriteres, og lyden bliver underbetonet eller helt overset. Denne forestilling ligger også implicit i titlen på en ny antologi, Blik for lyd (2014, red. Ansa Lønstrup m.fl.), der samler en række af landets mest kompetente og anerkendte lydforskere. Titlen spiller på en efterhånden klassisk metafor om forholdet imellem synet og hørelsen, og den lyder som et ekko af lydforskningens mest gængse pointe. Det kan således nok være, at titlen virker traditionel, men det forfriskende ved Blik for lyd ligger i dens nuancerede og flerstrengede tilgang til lyden.

Birger Langkjær har bidraget med en artikel om filmlydens rolle, eksemplificeret gennem udsnit fra bl.a. Tinker Tailor Soldier Spy og Drive. Langkjær indskriver sig i en kognitiv tradition, idet han ser på både det formelle lydlige udtryk og tilskuerens perception og lydoplevelse. Konkret skelner han imellem tre niveauer - det dramatiske niveau, det emotive niveau og det sensoriske niveau - og disse illustreres på pædagogisk vis gennem analyser af filmiske åbningssekvenser. Analyserne af anslagene til Drive og Tinker Tailor Soldier Spy virker da også velvalgte og billedskabende, ikke mindst i kraft af Langkjærs letflydende og stærke prosa. Hvorfor vi netop skal fokusere på disse film er dog mindre klart, og man kan undre sig over nogle små, men ikke helt ligegyldige petitesser: Hvorfor skifter instruktøren bag Lad den rette komme ind og Tinker Tailor Soldier Spy navn i løbet af artiklen, og hvorfor har man valgt netop de illustrationsbilleder fra filmene, oven i købet trykt i en bemærkelsesværdigt lav opløsning? Bortset fra sådanne redaktionelle småting, er Langkjærs artikel både 
veldrejet og velunderbygget. Samtidig må man rose forfatterens overlegne evne til gennem verbalsprogets begrænsede form at skabe et indre lydunivers for læseren, der næsten kan høre elektromusikken i Drive og fornemme det suspenseagtige lyddesign i Tinker Tailor Soldier Spy.

Langkjærs bidrag har et neoformalistisk tilsnit, mens Steen Kaargaard Nielsens artikel om Robbie Williams' musikvideoer er mere optaget af popsangerens persona- og imageforvaltning. Nielsen beskæftiger sig med popsangerens "konstante rolleskift og 'fiktionaliseringer"' (p. 48), og dette illustrerer han på overbevisende facon gennem forskellige betragtninger og velvalgte billeder. Hvor illustrationerne til Langkjærs bidrag kunne virke en anelse tilfældige, er billederne til Nielsens artikel både skarpere og mere pædagogiske.

Foruden Nielsens bidrag rummer Blik for lyd også to andre artikler om kortformater, hhv. Anders Bonde og Allan Grutt Hansens kvantitative undersøgelse om udtryksforsterkning og Charlotte Rørdam Larsen og Ansa Lønstrups digre og velskrevne artikel om det multisensoriske i reklamer. Bonde og Hansens artikel er fascinerende, og her er det tydeligt, at Blik for lyd udspringer af konkret forskning og primært henvender sig til forskningsmiljøet. Hovedpointen hos Bonde og Hansen er, at "den audiovisuelle helheds udtryk altid [...] overgår eller transcenderer delelementernes udtryk på uforudsigelig vis" (p. 159), og denne pointe er resultatet af en konkret dataindsamling fra diverse gymnasieklasser. Bonde og Hansen bygger på alt fra Eisensteins montageteori og Chions begreb om synchresis til de tanker om filmmusikkens rolle, som udfoldes i Adorno og Eislers bog Composing for the Films. Det særligt tiltrækkende ved artiklen er dog ikke dens teoretiske styrke, men dens videnskabelige fundament. Dette gør artiklen interessant for lydforskningen, men herved henvender den sig måske til en smallere læserskare end Langkjærs bidrag, og dette ser man også i selve sprogbrugen. Når forfatterne således, med bl.a. Cohen og Libscomb, stiller sig kritisk overfor "emergensbegrebets ontologiske realitet" og i stedet "plæder[er] for empirisk fundering" (p. 142), bliver det en anelse for akademisk til visse læsere.

Andre steder i bogen bliver sproget endnu mere akademisk. Nogle bidrag henvender sig specifikt til lydforskere, mens andre kunne læses på både bachelor- og sågar gymnasieniveau. Den mindst tilgængelige artikel er formentlig Mads Kroghs "Urbane assemblager", som indholdsmæssigt er ganske interessant, men som sine steder er næsten uigennemtrængelig. Krogh undersøger "forholdet mellem musik, lyd og lokalitet" (p. 98), og hertil bruger han Georgina Borns begreb om assemblager. Det er interessant at læse, hvordan brugen af mobile enheder indebærer nogle nye muligheder for en "lydligt iscenesat færden i urbane miljøer", men undertiden bliver det akademiske sprog en forhindring, som man skal komme forbi for at kunne fange de gode pointer. Krogh skriver bl.a.:

Man kan med en ekstrahering af træk ved Beers opregning af skæringspunkter betragte det forskningsfelt, som har udviklet sig vedrørende forholdet mellem musik, lyd og lokalitet, ad to kontinua - se figur 1. (p. 100) 
Blikfor lyd er naturligvis en akademisk udgivelse, men i eksemplet ovenfor bliver sproget næsten unødigt kompliceret. Dette kan man selvklart diskutere, og det piller ingenlunde ved de gode pointer i Kroghs artikel.

Andre bidrag er lettere at gå til. Iben Have og Birgitte Stougaard Pedersens artikel om mobile lydbøger, hvor de argumenterer for, at den mobile lydbog er en remediering af bogen, der forandrer vores lytte-læse-oplevelse, er eksempelvis klart og godt formidlet, og det samme gælder Thomas Bjørnsten og Annette Vandsøs bidrag "Lydlige henfald" og Nina Grams artikel "Byens koncert", som handler om forskellige lydvandringer i København. Grams artikel veksler mellem analytiske pointer og nogle umiddelbare refleksioner over hendes forskellige vandringer - refleksioner som er formidlet i en næsten skønlitterær og engagerende prosa.

Blik for lyd formår at afdække mange forskellige aspekter og funktioner af lyden i talrige kontekster og mediemæssige udtryk. Bogen er på mange måder vellykket, og den henvender sig naturligt til universitetsstuderende på Medievidenskab, Musikvidenskab og diverse kommunikations- og kunststudier. Bogen er dog også en slags opsamlingsplade over den foreløbige danske lydforskning, og dele af bogen bliver for akademiske til at kunne vinde genklang hos andre end forskningsmiljøet selv. Som en udenforstående læser kunne man godt ønske sig en større homogenisering, men man kan konstatere, at bogen er et overflødighedshorn af forskelligartede og interessante bidrag. Blik for lyd fortjener mere end blot et flygtigt blik, og den rummer nogle mere spidsfindige og nybrydende bidrag end dens titel antyder. Læs den eller hør den, så snart den udkommer som lydbog til dine mobile enheder.

Andreas Halskov Ekstern lektor ved Aarhus Universitet Redaktør af 16:9 andreashalskov@gmail.com 